\title{
Chapter 3 \\ Strengthening the Innovative Potential of Project-Based Learning for TVET
}

\author{
The USPECH Experience
}

\author{
Navbakhor Sharipova and Matthias Wesseler
}

\subsection{Introduction: The USPECH Project and Its Potential}

Current research suggests teacher quality is extraordinarily important and likely the most important factor in schools. (Hanushek 2015, p. 193)

The most important goal of introducing project-based learning is the promotion of innovative and productive thinking. (USPECH participant from Kazakhstan)

The purpose of the following article is to share some special experiences of the USPECH project, ${ }^{1}$ we understand as the core of the project's significant potential: "Promoting innovative and productive thinking" (see quotation above).

At a first look, the project may appear as one of those classic capacity building activities - valuable as they are, certainly - with a sequence of workshops to transfer some knowledge and to develop some skills or competencies. Beyond these activities, however, in USPECH all participants engaged in project work - and finally in reflecting, analysing and writing about their experiences and insights during the programme. These projects have been designed and implemented by the participants themselves, strengthening their ownership in the project, integrating cognitive and metacognitive dimensions at the individual level and their context's needs at the institutional one.

\footnotetext{
${ }^{1}$ In order to respect the GIZ terminology, we use the term "programs" for the system of TVET activities in Central Asia; for USPECH activities, we use the term "project"; the term "project" however most often is also used to refer to participants' learning and development activities, such as "project-based learning" or "project work". We trust that our text is sufficiently clear so that readers will not get confused by these differences.
}

N. Sharipova $(\triangle)$

German Corporation for International Cooperation (GIZ), Bishkek, Kyrgyzstan

e-mail:n.sharipova@unesco.org

M. Wesseler ( $\square)$

Faculty of Organic Agriculture, University of Kassel, Kassel, Germany

e-mail: matthias.wesseler@t-online.de

J. Drummer et al. (eds.), Vocational Teacher Education in Central Asia, Technical and Vocational Education and Training: Issues, Concerns and Prospects 28, https://doi.org/10.1007/978-3-319-73093-6_3 
The essence of USPECH, we believe, is emerging from a deeper level of projectbased learning (Christensen and Johnson 2011; Senge 1994) and its impact on both the professional everyday work of the project's partners and the curricular or institutional changes induced by the participants' projects. Since this level is somewhat hidden to traditional methods of empirical research, we use a "hybrid" style of methodology, combining empirical data from the project's formal quantitative monitoring activities, from the partners' project reports, from the narrative interviews at the end of the last workshop of July 2016 and from the authors' personal observations - and even intuition: "emotion and cognition are supported by interdependent neural processes" (Immordino-Yang 2016, p. 18). Furthermore, we trust that our cooperative writing as co-authors - one from Central Asia, one from Germany - will strengthen the credibility of our analyses. ${ }^{2}$ Thus, this paper will concentrate on underlying success factors, challenges of implementation and some emerging impacts based on the experiences of the USPECH project.

\subsection{Promoting Project-Based Learning: The USPECH Concept}

USPECH has been developed to complement the GIZ TVET project's efforts to design and to implement new curricula for food technology at BSc and MSc levels together with Central Asian partners: "Capacity building for TVET teachers and trainers in line with international standards is the necessary condition to meet the project's target" (GIZ 2015). Since 2008, GIZ has been successfully implementing a series of interrelated TVET activities in Central Asia and thus contributed to build a reliable basis of mutual trust and readiness to cooperate more closely in educational challenges: "Human capital, as we now call it, is extraordinarily important for a nation's economic development" (Hanushek 2015, p. 2).

The basic concept of USPECH has been designed in November 2014. The overall policy of USPECH is presented in this book's article by Stehling and Munzert (2018). Core elements have been an attempt to strengthen "ownership" - of problems, challenges and their solutions - based on individual project work and to develop the innovative power of professional "passion", recognizing that the quality of a student's teacher is the biggest factor in boosting that student's performance. In the frame of the overall goals - competence building for project work, networking and cross-regional cooperation - a series of workshops has been planned focussing on modules such as:

- Interactive teaching with a special view to project-based learning and teaching

- Media and instructional technologies (including online learning)

- Specific didactics and laboratory didactics

\footnotetext{
${ }^{2}$ Authors wish to express their gratitude to all USPECH partners for their openness to share their deeper learning results and professional impacts of project-based learning.
} 
- Modern forms of quality exams (effective grading, competence-based examinations)

- Scientific writing and preparation for a joint publication

Beyond the activities within the field of project work and the modules mentioned above, an excursion to Germany took place, and a strong element of quality assurance has been a crucial aspect of USPECH from the very beginning. It was planned to disseminate the USPECH experiences in a publication and to discuss successes and challenges in an international conference (to be held in April 2017). GIZ offered additional support for laboratory equipment and invited a team of experts from the Technical University of Dresden, the Free University of Berlin and from the University of Kassel. Furthermore the GIZ office built a highly competent and committed support team assuring the smooth and effective operational development of USPECH activities.

Within the frame of innovative quality and sustainable development of TVET teacher training in food technology, the following indicators have been suggested as "expected results" (November 2014):

- Participants, satisfied and empowered with a higher degree of competence and motivation

- 18 projects successfully designed and implemented

- A book to disseminate USPECH's experiences finished for publication

- A professional network established at the regional level, including a coordinating team and an agenda for the near future

After some modifications according to the needs of partners and to the possibilities of GIZ, activities started with an invitation of potential participants to design and present their own projects in early 2015 as kind of an application procedure to participate in USPECH. This was a first significant success, showing the interest and thus the ownership of partners in Central Asia and beyond: 18 projects from different countries, institutions and teams have been presented. Out of these teams, 30 partners have been invited personally to join USPECH and to form an innovative learning community with view to the decisive source of "project-based" learning (see below). Several of these participants had also attended earlier GIZ workshops, a fact which facilitated an advanced teaching and learning mode from the beginning. In March 2015, the first workshop started in Dushanbe.

\subsection{Presenting the Projects: The Essential Source of Significant Learning}

The first workshop in the framework of the USPECH programme launched the work of project-based learning by recognizing the significance of our partners' project designs. Theories of project-based learning have been shared and discussed as well as experiences in TVET contexts in other countries. 
Then the project management concept was introduced. The participants were equipped with tools to refine and modify their individually designed projects for future implementation. The importance of projects' originality, actuality, clear objectives, as well as potential risks of failure and complexities in implementation was specified. Moreover, participants were introduced into phases of project management (initiating, planning and implementation, control and completion of projects). Project teams have been given tips on a successful implementation of projects, by the following: setting clear requirements and documenting them in advance, clarifying roles and competences, ensuring the availability of resources before starting the project, involving all members of the team and informing them of the success of work.

Introduction into the theoretical background of project management supported by practical experience and examples triggered the motivation for implementation of 18 successful projects (9 from Tajikistan, 7 from Kyrgyzstan and 2 from Kazakhstan cf. Table 3.1).

Projects covered topics that have been specified in the call for application, namely, project-based learning, specific didactics, media and new technologies, evaluation of competencies, curriculum development, planning and organization of a study process, student coaching, etc.

Working on the projects has shown to be a living organism that could be changed, modified an adapted through the course of their development: some topics were narrowed down, some projects changed their objective and some teams adapted them more narrowly to the goals of their institution. A high motivation and commitment of partners and loyalty and interest of experts resulted in a trustworthy cooperation and accomplishment of outlined goals. However, achievement of the goals goes beyond the planned objectives of the programme. Taking a glance at the numbers that are drawn from interim reports and evaluation forms shows that participants' progress on their project work can be resumed. In addition to the reports, interviews with the participants have revealed some of the inner progresses that cannot quantitatively set a value on and measured.

Participants expressed their feelings of contentment about the development their projects brought to their professional and personal lives. Most of the partners, for example, appreciated the introduction into media and new technologies that "... changed their mindset from conservative to being more open to new technologies, thus impacting the whole working process and improving the organization of work". Besides the network in the professional sphere, participants built up strong ties with colleagues and the GIZ expert team by "... finding good friends, getting acquainted with Central Asian and German culture, and launching new mini projects in cooperation with colleagues and experts". Moreover, USPECH triggered some change in teachers' perception by “... developing a more tolerant attitude towards students' mistakes during studies, joint problem solution triggered by the coaching seminar, realizing the power of team work, using their communication skills in treating colleagues and students, replicating the most efficient part of experts' working format and design in their seminars and lectures" (quotes derived from the interviews, July 18, 2016). 
Table 3.1 Projects implemented in the framework of USPECH

\begin{tabular}{|c|c|c|}
\hline \# & Title & Institution \\
\hline 1 & $\begin{array}{l}\text { Development of business games for formation of } \\
\text { professional competence in Masters of Vocational } \\
\text { Education }\end{array}$ & $\begin{array}{l}\text { Kyrgyz State Technical University } \\
\text { named after I. Razzakov }\end{array}$ \\
\hline 2 & $\begin{array}{l}\text { Development of teaching methodical complex for the } \\
\text { course "Media Didactics" for Master of Professional } \\
\text { Education }\end{array}$ & $\begin{array}{l}\text { Kyrgyz State Technical University } \\
\text { named after I. Razzakov }\end{array}$ \\
\hline \multirow[t]{2}{*}{3} & $\begin{array}{l}\text { Curriculum development. Basic part. Direction: } \\
\text { Vocational education }\end{array}$ & \multirow[t]{2}{*}{$\begin{array}{l}\text { Kyrgyz State Technical University } \\
\text { named after I. Razzakov }\end{array}$} \\
\hline & Academic degree: Master & \\
\hline \multirow[t]{2}{*}{4} & $\begin{array}{l}\text { Development of a didactical approach in "Lab } \\
\text { Didactics" on the theme: }\end{array}$ & \multirow[t]{2}{*}{$\begin{array}{l}\text { Kyrgyz State Technical University } \\
\text { named after I. Razzakov }\end{array}$} \\
\hline & $\begin{array}{l}\text { "Production of hard cheese" for Master students of } \\
\text { Vocational Education in Food Technology }\end{array}$ & \\
\hline 5 & Creativity in the framework of the subject "Rhetoric" & Kyrgyz State Agrarian University \\
\hline 6 & $\begin{array}{l}\text { Improvement of planning an educational process, } \\
\text { content and pedagogical means (on the example of } \\
\text { food technology) }\end{array}$ & $\begin{array}{l}\text { Kyrgyz Republican National } \\
\text { Methodological Centre under } \\
\text { Agency of Vocational Technical } \\
\text { Education }\end{array}$ \\
\hline 7 & $\begin{array}{l}\text { Interactive learning methods as a means of improving } \\
\text { the quality of the educational process }\end{array}$ & $\begin{array}{l}\text { Karabalta Technical Economic } \\
\text { College }\end{array}$ \\
\hline 8 & $\begin{array}{l}\text { Organization of project activities of Master of } \\
\text { Professional Pedagogy }\end{array}$ & $\begin{array}{l}\text { Eurasian Technology University of } \\
\text { Almaty }\end{array}$ \\
\hline 9 & $\begin{array}{l}\text { Development of professional and pedagogical potential } \\
\text { of bachelor students of vocational education based on } \\
\text { an innovative approach to the educational process at the } \\
\text { university }\end{array}$ & $\begin{array}{l}\text { Karaganda State Technical } \\
\text { University }\end{array}$ \\
\hline 10 & $\begin{array}{l}\text { "Improving the competitiveness of teachers in the } \\
\text { labour market of Tajikistan" }\end{array}$ & $\begin{array}{l}\text { Technology University of } \\
\text { Tajikistan }\end{array}$ \\
\hline 11 & $\begin{array}{l}\text { "Improvement of laboratory equipment at Technology } \\
\text { University of Tajikistan" }\end{array}$ & $\begin{array}{l}\text { Technology University of } \\
\text { Tajikistan }\end{array}$ \\
\hline 12 & $\begin{array}{l}\text { Innovative educational technologies in teaching the } \\
\text { subject "food chemistry" for students of specialization } \\
\text { "Technology of Food Production" }\end{array}$ & $\begin{array}{l}\text { Technology University of } \\
\text { Tajikistan }\end{array}$ \\
\hline 13 & $\begin{array}{l}\text { Innovative educational technologies in teaching the } \\
\text { subject "Microbiology of Industry" for students of } \\
\text { specialization "Food Processing" with the major in } \\
\text { "Technology of bread, pastry and pasta" }\end{array}$ & $\begin{array}{l}\text { Technology University of } \\
\text { Tajikistan }\end{array}$ \\
\hline 14 & $\begin{array}{l}\text { Improving the quality of education on the basis of } \\
\text { computer-aided design (CAD) }\end{array}$ & $\begin{array}{l}\text { Technology University of } \\
\text { Tajikistan }\end{array}$ \\
\hline 15 & $\begin{array}{l}\text { Ensuring food safety by (further) training of teachers } \\
\text { based on the programme of standardization and } \\
\text { certification of food industry }\end{array}$ & $\begin{array}{l}\text { Technology University of } \\
\text { Tajikistan }\end{array}$ \\
\hline 16 & $\begin{array}{l}\text { "Development of curricula for the courses on further } \\
\text { training and retraining" }\end{array}$ & $\begin{array}{l}\text { Republican Institute for further } \\
\text { training and retraining of } \\
\text { Tajikistan }\end{array}$ \\
\hline
\end{tabular}


Table 3.1 (continued)

\begin{tabular}{l|l|l}
\hline$\#$ & Title & Institution \\
\hline 17 & $\begin{array}{l}\text { Introduction of laboratory didactics in the courses on } \\
\text { further training and retraining of professional education }\end{array}$ & $\begin{array}{l}\text { Republican Institute for further } \\
\text { training and retraining of } \\
\text { Tajikistan }\end{array}$ \\
\hline 18 & $\begin{array}{l}\text { Further training of teachers on the preparation of } \\
\text { laboratory teaching materials on food technology }\end{array}$ & $\begin{array}{l}\text { Isfara Branch of Technology } \\
\text { University of Tajikistan }\end{array}$ \\
\hline
\end{tabular}

\subsubsection{Approaching the Innovative Potential of USPECH'S Project-Based Learning}

\subsubsection{USPECH'S Impact: What Kind of Data Are We Using?}

The word ,learning' undoubtedly denotes change of some kind. To say what kind of change is a delicate matter. (Bateson 1987, p. 287)

This famous quote seems to be even more valid today, almost 50 years later, if we listen - for example - to the recent discourse in educational spheres on competence-based learning or to the research debates in neuroscience, as Antonio Damasio argues in his chapter "Educating the Cognitive Unconscious" (2012, p. 280): “... many questions remain ..." (id. 2012, p. 132) ... "In the past few decades the understanding of learning has deepened to the level of molecular mechanisms and gene expression" (id. 2012, p. 303).

Assessing, hence, the impact of programmes like USPECH is always a challenge, and GIZ for decades has tried to design reliable und valid chains of effects ("Wirkungsketten", GIZ 2015; cf. also Sebe-Opfermann 2013, on impacts of project-based learning in TVET contexts). Furthermore, in the USPECH context of continuous translations between German, Russian and English, we realized that there aren't any recognized standard definitions, even in the same language. The same word - competence, for example, passion or learning objectives - means different things to different people.

Although a mechanistic seamless chain of cause and effect in a complex educational context is beyond any effort of monitoring and evaluation, USPECH established from the beginning a system of quality assurance (cf. Drummer 2018) in order to understand progress, challenges and failures - and to learn from them.

The search for impact, accordingly, may start with sharing the sources of data we used to observe and monitor the programme. Basically we dispose of five different kinds of data:

- The original project designs by the partners, including stated objectives and approaches (18 texts) focusing on tangible results, sharing own values (!), clear agenda incl. resources and documentation, supported by institutional heads

- Workshop evaluation questionnaires (with a rather quantitative approach) (approx. 85 questionnaires from partners and some filled in by the GIZ staff and experts) and documented oral feedback at the end of the workshops 
- Structured interim reports written by the partners on their project work's progress (combining quantitative and qualitative data) (34 reports)

- Narrative interviews with a sample of partners during the final workshop (July 2016; ten interviews)

- Participatory observations during workshops and meetings (with a qualitative focus)

The written and oral feedback produced many comments with rather positive assessments by our partners like "we need more of this kind of quality workshops" or "USPECH operates at the highest level: interesting, professionally effective and scientifically rich". These comments certainly convey an important message for the immediate further planning of the programme, even keeping in mind some kind of politeness bias involved. For a deeper analysis, we would however need more specific data to understand the potential impacts of USPECH. In general we believe that we can share with a high degree of validity, reliability and credibility in three different areas of the programme's induced impacts (Wesseler 2017):

- Individual learning, at different levels

- Institutional learning and change

- Learning as evolution of the "cooperating system" (GIZ 2015, p. 80)

\subsubsection{Impact on Individual Learning: Innovative and Relevant Personal Growth}

The current European debate on competence-based learning is just one more example of the efforts to observe and understand the enormous complexity of individual learning, let alone organizational or even "regional learning". For our purpose with special focus on project-based learning, we choose a rather biological and brainscience-based approach (Bateson 1987; Damasio 2012; Immordino-Yang 2016; Maturana and Varela 1992), where different levels of learning are observed. The most basic seems to be an accumulative process of gathering new information and skills (proto-learning). At a higher level, learning is happening within a deeper neural level generating new connections and constructing systems of knowledge, skills or competences (deutero-learning), and finally - with a high degree of metacognitive interactions - there seems to be a third level which is the most difficult but also the most productive and powerful one: a learning which develops new learning modes or mental models or mindsets (Senge 1994), or simply "learning to learn", not in a "sustaining" or "incremental" mode but rather "braking through" prior learning habits and thus contributing efficiently to "disruptive innovations" in perceptions, values, attitudes and actions (Christensen and Johnson 2011; Christensen et al. 2015).

This approach is close to the famous "pillars of learning", as designed by UNESCO: "learning to know", "learning to do", "learning to be" (!, added by authors) and "learning to live together" (Delors 1996). USPECH'S strong emphasis on 
"passion" for learning appears in this theoretical framework as a necessary condition for relevant metacognitive learning, recognizing "the fundamental role of emotions in learning" (Immordino-Yang 2016, p. 17).

The original designs of the partners' projects reveal an underlying set of quite innovative motivations and approaches, such as "I want to learn innovative educational methods which generate a motivational context for independence and intellectual self-reliance" (Tajikistan) or "The basis of education today should be formed not by subject matter but rather by a new mode of thinking and acting" (Kazakhstan) or "The main purpose of teaching should be to support the creative potential of our students" (Kyrgyzstan).

Thus, there was, already from the beginning, a high and significant readiness potential for innovative learning and work. Participants have been aware of the urgent need of innovation and change not just in their own teaching and research methods but also in general in their countries' TVET systems: "passion for learning" (Sarder 2016, XIX) became an underlying driver of the USPECH programme.

Similarly, partners have been aware of the need to create "a radical shift of mind set" (Senge, according to Sarder 2016, p. 173): "I want to fill myself with new energies and innovative potential" (USPECH partner's expectation) in order to be able to connect individual learning, innovation and institutional change. Accordingly, the USPECH programme challenged participants "with going deeper in conceptual knowledge, employing critical thinking skills" (Warren and Ott 2016, p. 2).

Taking a closer look on the project's partners' comments on their own learning results, we can observe a whole list of different professional knowledge and skills or competences at the first level (proto-learning), which partners did acquire from USPECH attendance and - most significantly - from their own project work: "Deepened knowledge on project management and scientific writing" (quotation from workshop questionnaire) (Fig. 3.1).

Going beyond these "incremental" or "sustaining", mostly cognitive learning outcomes at the first learning level (proto-learning, see above), we can observe at a deeper level also some highly significant metacognitive results (known as deuterolearning; see above, Bateson 1987).

It is not the directly offered workshop's content which seems to matter most but rather the underlying message of different modes of communication, interaction and teaching. First of all we observe a growing transfer competence from the workshop sessions towards the everyday practice of the ongoing project work (Adapted from Drummer 2016) (Fig. 3.2).

Another highly relevant learning outcome shows up in the workshop evaluations, such as growing cooperation amongst the partners themselves (Fig. 3.3).

Cooperation of partners has been valued as highly relevant and innovative because of the general academic culture which is rather based on individual efforts, especially in our partners' Central Asian institutions but also in most German universities or TVET colleges. Learning to work effectively in a team, as data showed, became an essential competence for project success. The generation of communities of learning or "communities of inquiry" (Kaliva 2015) copes with this essential 


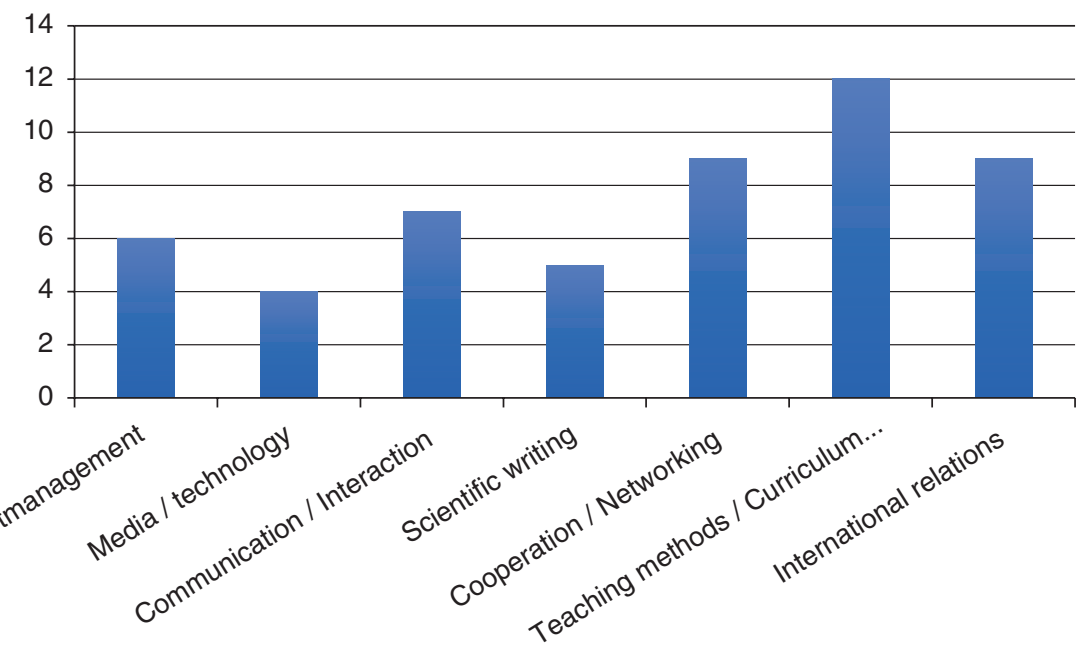

Fig. 3.1 Areas of acquired knowledge and competences (as expressed July 2016)

I could transfer the contents of the workshops to my project

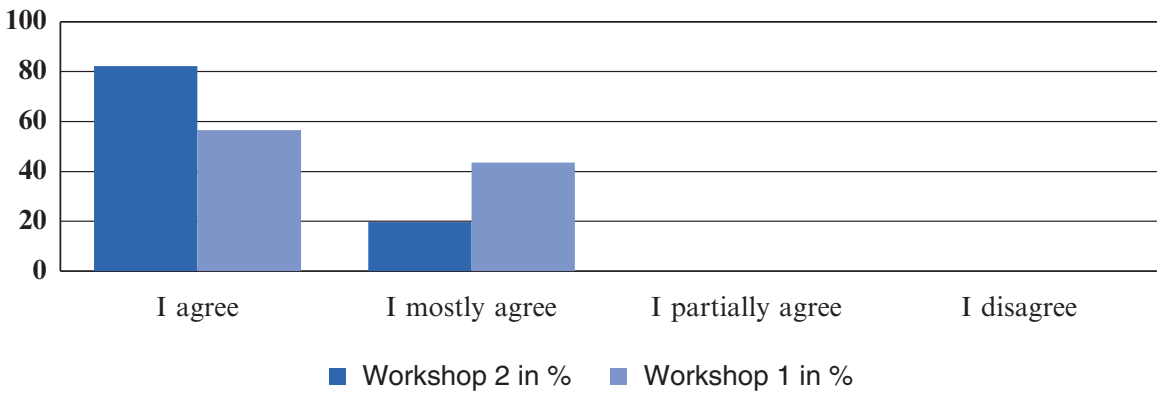

Fig. 3.2 Transfer of workshop topics to project work according to the first and second workshop

USPECH goal of regional networking: "I found a positive breakthrough to move forward in my work" (USPECH partner's interview, July 2016) or - just to mention one more partner's view - "These workshops are necessary, because they promote cooperation in TVET through sharing experiences and strengthening professional competences" (quoted from an questionnaire assessing workshop IV, July 2016).

Partners often mentioned that the excursion to Germany was not just an important incentive for them but rather a decisive learning opportunity with overwhelmingly complex experiences of being exposed to rather different kinds of TVET teaching and learning, such as innovation towards more student centeredness, openness or demand-based and independent teaching and learning.

In summary, USPECH shows that deeper learning and growing ownership are needed as success factors: 
I arranged future cooparations with fellow participants.

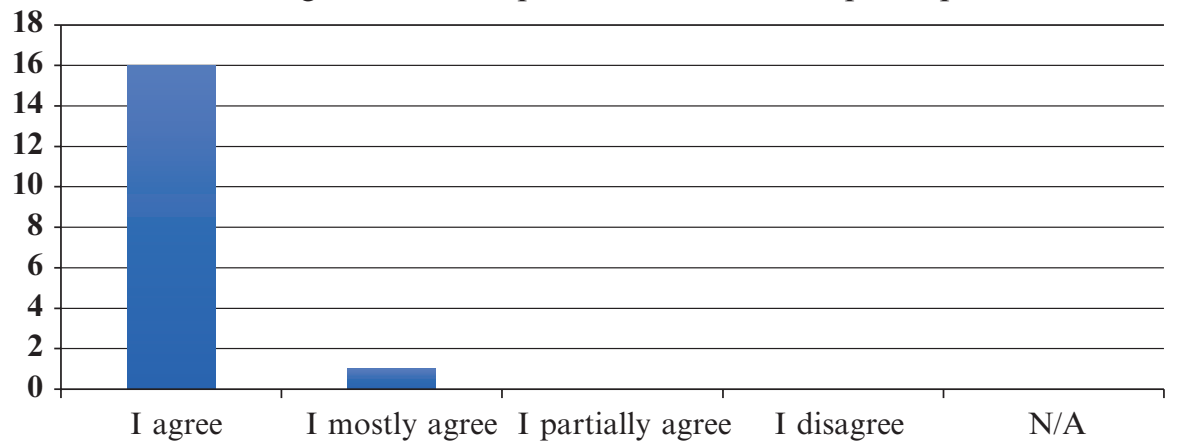

Fig. 3.3 From USPECH monitoring and evaluation activities (Adapted from Drummer 2015): assessing readiness potential for cooperation between partners

- A readiness potential from the beginning, for both partners and organizers and experts

- Followed by attractive relevant workshop inputs, methods, interactions and excursions

- Which finally succeed to create a space for productive and innovative personal growth

Now, we ourselves take the challenges in our own hands. (A partner's oral feedback, July 2016)

\subsubsection{Impact on the Institutional Learning: Innovative Teaching, Communication and Cooperation}

One fundamental value of project-based learning depends on the balance of individual learning through project work (teams, management, materials, equipment, etc.) and the effect of the project's impacts, intended or unintended, on the professional institutional context: Since the original project designs have all been approved by the authorities of our partners' institutions, it was clear that these projects would gain an impact not just for the individuals involved but also for institutional learning and change: Project-based learning generates not only new knowledge and competences for the participating individuals but also change and innovation in their institutional contexts.

The second interim reports of the projects (March 2016) and other sources reveal a broad area of our partners' projects' influences at the institutional level:

- Progress in curriculum development (B. Sc. and M. Sc.): “... we launched a new Master's program, and the teaching will be according to the plan I developed" (USPECH partner's interview, July 2016). 
- Institutional development through strengthened cooperation, sharing and capacity building: "I involved other staff of our Department and conducted scientific and methodical seminars" (USPECH partner's interview, July 2016); participating partners shared teaching materials, even beyond institutions.

- Opening up to closer cooperation with the private sector (a strong USPECH dimension!), designed, for example, several competence matrices - together with private sector representatives - for TVET graduates in food technology.

- Methodological and didactic innovations, such as role play, new laboratory methods of teaching and learning and design of modern, especially competencebased examinations (cf. Golubina and Löser 2018).

In spite of the general scarcity of resources, as continuously mentioned by the partners, they were able to upgrade their laboratories (with some support from GIZ), to improve their media equipment and to experiment with online learning activities. Sometimes these efforts resulted in personal promotions, in publications, in invitations to international congresses, in the development of innovative learning materials for the students and even in national quality awards.

It certainly would not be correct to claim all this as impacts by our partners' participation in USPECH. Our partners took their own learning in their "hands" and "hearts". The purpose of ownership and sustainability however guided the design of the workshops: "All that I learn during the seminars I analyse afterwards. I do not take all the knowledge, I take some elements. I squeeze the juice and then apply it when it is necessary" (a partner's interview statement, July 2016).

Beyond these significant success stories, there also have been challenges in the programme's progress such as the constant need for translation and its difficulty to define terms adequately in different languages; some institutional partners' contexts with their corresponding projects could not be aligned to the innovative learning processes during the programme (two projects even dropped out). In some cases GIZ was not in a position to assure all the equipment desired for the implementation of the designed projects, contributing thus to a certain degree of initial frustration.

Apparently - in some cases - the growing knowledge and competence of our participating partners contributed to generate some discomfort or even stress within their faculties: "people were even jealous" (a partner's interview statement, July 2016). Innovations always cause irritation, and it is one of the crucial challenges to transform those irritations into positive drivers of institutional change.

USPECH however created a "space" for sharing those challenges strengthening mutual recognition of efforts and support far beyond the face-to-face meetings during our workshops: "The most valuable message I got was that even with minimal resources one can achieve great results" (a partner's interview statement, July 2016). USPECH has been contributing to allow our partners to "boldly develop their own activities" as Franz Horlacher, a colleague of the international expert team, summarized his observations. Thus, the carefully growing ownership - not just of what a person learns but also of what she or he implements into her/his institutional context - is decisive. The priority of ownership in USPECH may lead to "breakthrough" innovations, which "disrupt" (Christensen et al. 2015) an obsolete mindset, some- 


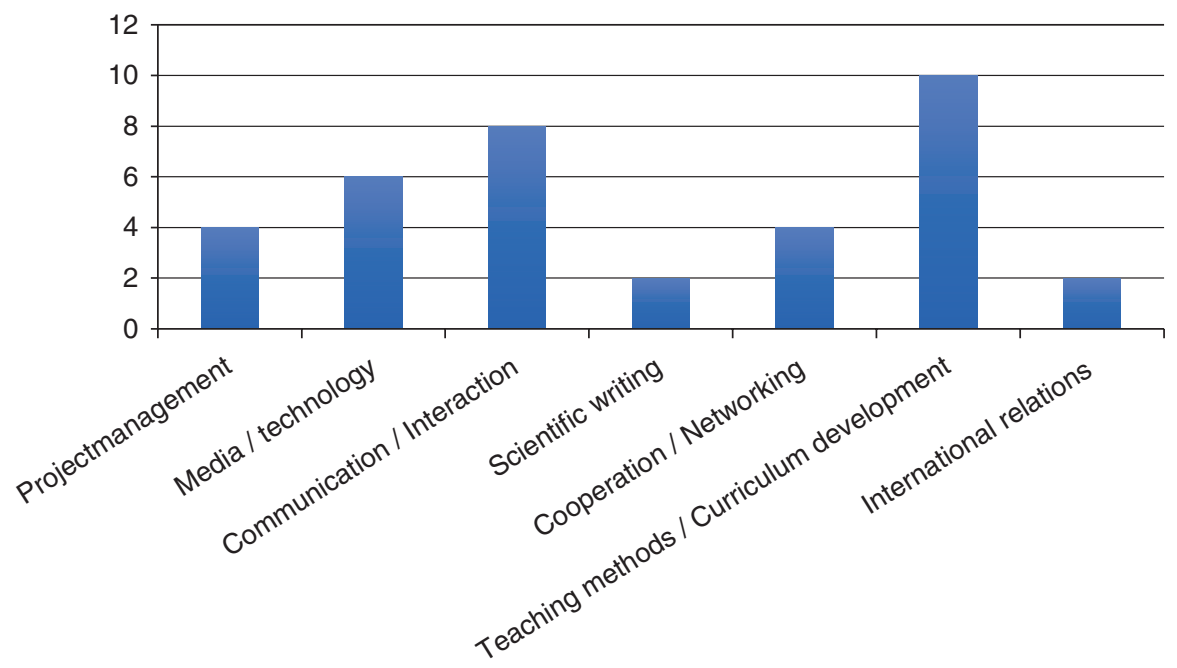

Fig. 3.4 Acquired competences implemented in everyday work

times to be observed in international TVET cooperation, where transferring knowledge is seen as more important than creating space for shared inspirations, personal empowerment and productive cooperation.

It is interesting then, to compare our partners' observations concerning their own learning results with their efforts to implement the most relevant things into their everyday professional practice: Beyond all specific topics offered during the workshops - valuable as they are, of course - it is "innovative teaching methods" and "communication and cooperation" amongst colleagues within their institutions and sometimes even internationally what mattered most (Fig. 3.4).

"The most important part for me is what I apply in relation to my colleagues: Good ways of treating people" (a partner's interview statement, July 2016). This is close to the essential fourth UNESCO pillar "Learning to live together" (Delors 1996) and has certainly an effect on the sustainability of the programme even beyond TVET and food technology: "There was a dream that we would have access to the educational and scientific sphere - the dream came true" (a partner's interview statement, July 2016).

\subsubsection{Evolving the "Cooperating System": GIZ and Experts}

Unfortunately, our reliable data of understanding USPECH's impact on the "cooperating system" itself are relatively weak: There have been questionnaires for us the so-called experts and the GIZ staff involved - as well; some, however, have not 
been answered; others to our dismay, but understandably in view of the huge amount of data to be handled, have been lost. Our observation hence is mainly based on the authors' own intuition, a highly significant source of knowledge and insight according to neuroscience scholars such as Damasio (2012) or Immordino-Yang (2016).

What did we ourselves learn? How did our cooperation with USPECH impact our own way of seeing the world and constructing our own learning architecture? GIZ claims that this kind of learning is an essential "success factor" of cooperation (GIZ 2015, p. 80): "Learning as evolution" (id., 2015, p. 83).

A rough summary may contain the following issues:

1. A deeper understanding of the truly innovative potential of project-based learning for TVET teachers' capacity building; this will strengthen not only the effectiveness of participants' work but also the future employability of their graduates.

2. Ownership of participants is more essential to relevance and sustainability than brilliant scientific lessons (necessary as they are!): The potential of people, even if sometimes concealed in a "tacit" mode, finally makes the difference. Therefore, USPECH started with an invitation process built on the quality of participants' independent project designs.

3. Creating space for open and independent learning, for motivation and inspiration, should get more attention (cf. Köhler 2017); in this context, also the rich potential of the partners' projects should be recognized with more thoroughness.

4. Cooperation and networking amongst partners will be of growing importance to cope with sustainable development in TVET - and will possibly require further support from GIZ, especially with view to the regional challenges and potentials of food technology in Central Asia ("learning regions").

5. Multiplication of the core lessons learnt - via conferences, articles or books - is essential: again and again.

6. The quality of a programme such as USPECH also depends decisively on the quality and commitment of an organizing team and the smooth cooperation of invited experts.

According to a quotation from the staff's anonymous questionnaire (Workshop IV, July 2016), one of our colleagues summarized her or his assessment: "The opportunity to work independently has been used intensively by all partners ... we achieved more than we had thought at the beginning".

Certainly, GIZ together with the USPECH experts' team - and certainly together with all our partners - is on a good way to cope more closely with the recent UNESCO demands on TVET: "UNESCO is at the forefront of global debates on the future of education and learning [...] external demands on TVET systems go far beyond the familiar call for TVET to contribute to economic growth, employment and competitiveness. Today, TVET is considered to be a crucial vehicle for social equity and inclusion, as well as for the sustainability of development" (Marope et al. 2015, p. 8). 


\subsection{Conclusions: Sustainable Learning}

"Who survives? Education decides on the future of humankind" (Klingholz and Lutz 2016): Global statistical data do not leave any doubt (cf. Hanushek 2015) about the decisive significance of education, especially TVET - and of the decisive importance of the quality of teachers.

Project-based learning is gaining growing recognition for its relevant and innovative learning impacts on both individuals as well as on institutions (Boss 2015; Warren and Ott 2016). This is the underlying context of USPECH within a setting of challenging socio-economic needs and educational conditions in the partner countries of Central Asia. Since 2008, GIZ is supporting relevant initiatives in curriculum design and human capital building (especially teacher training), starting from a rather centralistic approach inducing entire modules into existing curricula and moving in recent years towards a growing confidence in the competence of local partners.

If we carefully listen to our partners' voices, we do not hear a unanimous cheering and rejoicing of the USPECH project. Beyond all nuances and differences, there is however a powerful message: What is appreciated most is the recognition of our partners' potential - and the trust in their professional readiness to cope with the challenges: recognition and trust balanced with efficiency and monitoring. There is a clear tendency towards more independence in learning, especially in project-based learning. Obviously, partners appreciate workshops and inputs, materials and lessons, the presentations of new technologies and educational innovations but not as instructions to be followed. The added value of workshops and other inputs of the USPECH project have been perceived more as necessary tools to generate an open space for sharing, cooperation, mutual learning - and implementation. What seems to matter to them is rather the recognition of a larger mutual challenge amongst themselves and the GIZ team, including experts - and a common effort to support each other within the context of one's own institutional, cultural and economic constraints: "We take the necessary change in our own hands" (feedback quote from workshop participants, July 2016).

Certainly, this is an ongoing process. Learning never ends and certainly not project-based learning. USPECH is not a destination but rather one more step towards a sustainable, relevant and innovative development in Central Asia's TVET on its way to cope with the enormous challenges of effective teaching and learning and of assuring the high-level employability of future TVET graduates.

\section{References}

Bateson, G. (1987). Steps to an ecology of mind: Collected essays in anthropology, psychiatry, evolution, and epistemology (Reprint [d. Ausg.] San Francisco, Chandler Pub., 1972). Chandler publications for health sciences. Northvale: Aronson.

Boss, S. (2015). Implementing project-based learning. Solutions for digital learner-centered classrooms. Bloomington. In: Solution TreHorn, M. B.e Press. 
Christensen, C. M., \& Johnson, C. W. (2011). Disrupting class: How disruptive innovation will change the way the world learns (Expanded ed.). New York: McGraw-Hill Education.

Christensen, C.M., Raynor, M.E., McDonald, R. (2015). What is disruptive innovation? Harvard Business Review, (12), 44-53. Retrieved from https://hbr.org/2015/12/ what-is-disruptive-innovation

Damasio, A. R. (2012). Self comes to mind: Constructing the conscious brain. London: Vintage.

Delors, J. (1996). Learning: The treasure within: Report to Unesco of the international commission on education for the twenty-first century. Paris: Unesco Publ.

Drummer, J. (2015). Evaluation report for the project USPECH. unpublished. Bishkek.

Drummer, J. (2016). Evaluation report for the project USPECH. unpublished. Bishkek.

Drummer, J. (2018). Quality management for projects and workshops. In J. Drummer, G. Hakimov, M. Joldoshov, T. Köhler, \& S. Udartseva (Eds.), Vocational teacher education in central Asia: Developing skills and facilitating success. Berlin: Springer.

Engel, C.. (2010). Emerging transformation in higher education: Concepts - projects - networking; proceedings of the International UNISTAFF Forum, March 2009, Kassel University, Witzenhausen; [university staff development programme Witzenhausen]. Kassel: Kassel University Press. Retrieved from www.uni-kassel.de/upress/online/.../978-3-89958-966-5. volltext.frei.pdf

Gesellschaft für Internationale Zusammenarbeit (GIZ). (2015). Kooperationsmanagement in der Praxis: Gesellschaftliche Veränderungen gestalten mit Capacity WORKS. Wiesbaden: Springer Gabler. Retrieved from https://doi.org/10.1007/978-3-658-06276-7.

Golubina, E., \& Löser, A. (2018). Competency-based examinations in professional education. In J. Drummer, G. Hakimov, M. Joldoshov, T. Köhler, \& S. Udartseva (Eds.), Vocational teacher education in central Asia: Developing skills and facilitating success. Berlin: Springer.

Hanushek, E. A. (2015). The knowledge capital of nations: Education and the economics of growth (CESifo Book Series). Cambridge, MA: The MIT Press. Retrieved from http://gbv.eblib.com/ patron/FullRecord.aspx? $=3339973$

Hattie, J. (2012). Visible learning for teachers: Maximizing impact on learning. London: Routledge.

Immordino-Yang, M. H. (2016). Emotions, learning, and the brain: Exploring the educational implications of affective neuroscience (first edition). The Norton series on the social neuroscience of education. New York: W.W. Norton \& Company.

Kaliva, E. (2015). Didaktische Implikationen des projektbasierten Lernens beim Einsatz von Social Learning Environments in Hochschulen (Dissertation). Werner Hülsbusch.

Klingholz, R., \& Lutz, W. (2016). Wer überlebt?: Bildung entscheidet über die Zukunft der Menschheit (1. Aufl.). s.1.: Campus Verlag.

Köhler, T. (2018). Learning performance in vocational secondary schools: Testing academic achievement in electrical engineering. In J. Drummer, G. Hakimov, M. Joldoshov, T. Köhler, \& S. Udartseva (Eds.), Vocational teacher education in central Asia: Developing skills and facilitating success. Berlin: Springer.

Laur, D. (2013). Authentic learning experiences: A real-world approach to project-based learning. Hoboken: Taylor and Francis.

Marope, P. T. M., Holmes, K. P., \& Chakroun, B. (2015). Unleashing the potential: Transforming technical and vocational education and training. Education on the move. Paris: UNESCO Publishing.

Maturana, H. R., \& Varela, F. J. (1992). The tree of knowledge: The biological roots of human understanding (Rev ed.). Boston: Shambhala.

Rummler, M., Nehls, T., Jordan, P., \& Heitmann, G. (2012). Innovative Lehrformen: Projektarbeit in der Hochschule: Projektbasiertes und problemorientiertes Lehren und Lernen (1. Aufl.). Hochschuldidaktik. Weinheim: Julius Beltz.

Sarder, R. (2016). Building an innovative learning organization: A framework to build a smarter workforce, adapt to change, and drive growth. Hoboken: Wiley.

Sebe-Opfermann, A. (2013). Kooperation in projektbasierten Lehr-Lern-Arrangements: Eine empirische Analyse von Wirkungen und Wirkungszusammenhängen. Zugl.: Bremen, Univ., Diss., 2011. Internationale Hochschulschriften: Vol. 567. Münster: Waxmann. 
Senge, P. M. (1994). The fifth discipline: The art and practice of the learning organization (1. Currency paperback ed.). New York: Currency Doubleday.

Stehling, C., \& Munzert, U. (2018). Project based learning. In J. Drummer, G. Hakimov, M. Joldoshov, T. Köhler, \& S. Udartseva (Eds.), Vocational teacher education in central Asia: Developing skills and facilitating success. Berlin: Springer.

Warren, A., \& Ott, M. G. (2016). Project-based learning across the disciplines: Plan, manage, and assess through +1 pedagogy. Thousand Oaks: Corwin, a SAGE Company.

Wesseler, M. (2010). Wesseler, M. (2013): Passion for learning: The shift towards learning for development in higher education. In C. Engel (Ed.), Emerging transformation in higher education. Concepts - projects - networking; proceedings of the International UNISTAFF Forum, March 2009 (pp. 25-38). Witzenhausen.; [university staff development programme Witzenhausen]: Kassel University. Kassel: Kassel Univ. Press. Retrieved from www.unikassel.de/upress/online/.../978-3-89958-966-5.volltext.frei.pdf

Wesseler, M. (2017). Evaluation und Evaluationsforschung. In R. Tippelt \& A. V. Hippel (Eds.), Handbuch Erwachsenenbildung/Weiterbildung (5th ed.). Wiesbaden: VS Verl. für Sozialwiss.

Open Access This chapter is licensed under the terms of the Creative Commons Attribution 4.0 International License (http://creativecommons.org/licenses/by/4.0/), which permits use, sharing, adaptation, distribution and reproduction in any medium or format, as long as you give appropriate credit to the original author(s) and the source, provide a link to the Creative Commons license and indicate if changes were made.

The images or other third party material in this chapter are included in the chapter's Creative Commons license, unless indicated otherwise in a credit line to the material. If material is not included in the book's Creative Commons license and your intended use is not permitted by statutory regulation or exceeds the permitted use, you will need to obtain permission directly from the copyright holder.

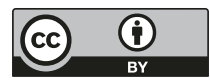

